\title{
O Controle do Terceiro Setor
}

THIRD SECTOR CONTROL

Inês Maria Coimbra de Almeida Prado(*)

Taiane Lobato de Castro ${ }^{(\star \star)}$

\section{RESUMO}

Este artigo tem como objetivo abordar as formas de controles legais exercidas sobre entidades do terceiro setor. $O$ trabalho inicia-se com a análise do autocontrole exercido pelas organizações sociais e organizações da sociedade civil de interesse público. Em seguida, aborda a fiscalização realizada pelo Poder Executivo e pelos Tribunais de Contas, finalizando com 0 controle exercido pela própria sociedade organizada. $O$ estudo ora apresentado não tem a ousadia de esgotar o assunto, mas, pretende ser fonte de informações sobre o controle de atuação das entidades do terceiro setor no ordenamento jurídico.

\section{Palavras-Chave:}

Controle Social; Organizações Sociais; Terceiro Setor.

\section{ABSTRACT}

This article has the objective of approaching the forms of legal controls on entities of the third sector. The work initiates with the analysis of the selfcontrol performed for the social organizations and the civil society organizations

(*) Procuradora do Estado de São Paulo, Mestranda em Direito Administrativo pela Pontifícia Universidade Católica de São Paulo (PUC/SP), especialista em Direito Administrativo e em Processo Civil, pela PUC-SP. Email: inesalmeidaprado@uol.com.br.

(**) Advogada, mestranda em Direito Administrativo pela PUC-SP, especialista em Direito Tributário pela PUC-SP, E-mail: taianelobato@bol.com.br.

Recebido em 15.12.06

Aprovado em 03.05.07 
of public interest. After that, it approaches the fiscalization carried through for the Government and the Justice, finalizing with the control practised for the society. This study does not intend to approach all the minimum details related to this theme, however it intends to be a source of information on the control of third sector organizations inside the legal system.

\section{Key words}

Social Control; Social Organization; Third Sector.

\section{AUTOCONTROLE}

A presente seção será dedicada à análise do controle exercido no interior das Organizações Sociais (OS) e das Organizações da Sociedade Civil de Interesse Público (OSCIPS), aqui denominado de autocontrole.

Tais organizações surgiram no cenário jurídico nacional por força da reforma do Estado, engendrada pelo então ministro Bresser Pereira como opção mais eficiente na prestação de serviços públicos ou serviços de relevância pública. Neste contexto, foram editadas no âmbito nacional as Leis n. 9.637, de 15 de maio de 1998 e n. 9.670, de 23 de março de 1999, disciplinando, respectivamente, a qualificação de pessoas jurídicas de direito privado como organizações sociais e organizações da sociedade civil de interesse público.

Até mesmo em razão da relação que se estabelece entre a administração pública e estas entidades, que prevê, entre outros, repasse de verbas públicas, os citados diplomas legais regulamentam o regime jurídico aplicável às OSs e às OSCIPs, disciplinando, inclusive, as diversas espécies de controle, dentre as quais aquela exercida no interior da pessoa jurídica.

Considerando-se as distinções existentes entre os regimes jurídicos aplicáveis às duas organizações aqui tratadas, por uma questão metodológica, procederemos à análise de cada entidade separadamente, perpetrando, ao fim, as comparações pertinentes.

\subsection{Autocontrole nas organizações sociais}

As organizações sociais surgiram como forma de implementar o fenômeno denominado, no campo da reforma do Estado, de publicização, transferindo para pessoas de direito privado a gestão de atividades não exclusivas do Estado. Ao menos inicialmente, o principal objetivo desta nova forma de 
gestão era a extinção de órgãos e entidades da administração direta e indireta e a absorção de suas atividades por organizações sociais( ${ }^{(1)}$.

Neste diapasão, a Lei n. 9.637/98 autoriza, uma vez firmado contrato de gestão, a possibilidade de repasse de recursos orçamentários e bens públicos imprescindiveis ao cumprimento do citado contrato (art. 12, $\S 1^{\circ}$ ) assim como a cedência especial de servidor público com ônus para a origem $(\text { art. 14) })^{(2)}$.

Imprescindivel, portanto, um rígido controle destas entidades.

Assim, no campo dos requisitos específicos para que as entidades privadas qualifiquem-se como organização social (art. $2^{\circ}$ Lei n. 9.637/98), cumpre ressaltar a exigência de conselho de administração com atribuições normativas e de controle básicos (inc. I, c).

Observe-se que a lei define a composição do Conselho de Administração, que deverá formar-se por representantes do Poder Público e membros da comunidade, respeitadas as proporções estabelecidas no art. $3^{\circ}$, inc. I. A proporção ali exigida garante aos membros do Poder Público expressiva representação eis que eles, somados aos representantes da sociedade civil, devem corresponder a mais de $50 \%$ do Conselho sendo que ainda indicarão outros $10 \%$ na forma da alínea $e$.

Esta formação deixa claro o intuito do legislador em manter o controle interno das organizações sociais preponderantemente nas mãos do Poder Público, fato que só corrobora a idéia de tratar-se este novel instituto de verdadeiro desvirtuamento das características fundamentais do terceiro setor, dentre as quais ser controlado pela sociedade.

A Lei Complementar n. 846/98, que dispõe sobre a qualificação de entidades como organizações sociais no âmbito do estado de São Paulo, não incorre no mesmo erro. Embora preveja a existência de Conselho de Administração com atribuições semelhantes, em sua formação não há obrigatoriedade de haver qualquer membro do Poder Público (art. 3ํ., 1).

Pois bem, é este Conselho de Administração que exercerá importante forma de autocontrole da organização social. A primeira delas é a aprovação e encaminhamento ao órgão supervisor da execução do contrato de gestão, dos relatórios gerenciais e de atividades da entidade, elaborados pela diretoria (art. $\left.4^{\circ}, \mathrm{IX}\right)$.

(1) Oportuno observar a ementa constante na Lei n. 9.697/98 que preceitua: "Dispõe sobre a qualificação de entidades como organizações sociais, a criação do Programa Nacional de Publicização, a extinção dos órgãos e entidades que menciona e a absorção de suas atividades por organizações sociais, e dá outras providências." Neste sentido é o disposto no art. 20 do mesmo diploma.

(2) Juarez Freitas alerta para o risco de privatização sem as devidas cautelas legais: "Assim criticado o regime, merece reiteração que o instituto das organizações sociais comporta riscos de utilização indevida, sobretudo se se prestar à privatização mais ou menos dissimulada, além de não incorporar as vantagens organizacionais próprias e caracteristicas do terceiro setor." O Controle dos atos administrativos e os Princípios Fundamentais, p. 286. 
Da mesma forma, incumbe ao Conselho de Administração a fiscalização do cumprimento das diretrizes e metas definidas no contrato de gestão (art. $4^{\circ}, \mathrm{X}$ ). Com efeito, o controle que se exerce sobre as atividades das organizações sociais é, em todas as instâncias, um controle eminentemente de resultados, ou seja, o fundamental é atingir as metas propostas no contrato de gestão, ainda que não haja controle tão estrito sobre os meios utilizados para tanto.

Destarte, o Conselho de Administração é a primeira instância para este controle por resultados, verificando se foram atingidas as metas definidas no contrato de gestão. Ressalte-se que o descumprimento de tais diretrizes e metas pode levar à desqualificação ${ }^{(3)}$ da entidade como organização social, com responsabilização de seus dirigentes por danos ou prejuizos causados por ação ou omissão (art. 16, $\S 1^{\circ}$ ).

O Conselho de Administração é competente, também, para a aprovação dos demonstrativos financeiros e contábeis e das contas anuais da entidade, com o auxílio de auditoria externa.

Verifica-se, aqui, uma preocupação do legislador, que se repetirá no controle da OSCIP, em implementar outro mecanismo de controle financeiro, para além do Tribunal do Contas, através de auditoria externa.

Nos termos da lei, esta auditoria externa auxiliará o Conselho de Administração no controle das contas da entidade. Todavia, a lei é lacunosa quanto à especificação deste controle ficando a cargo do contrato de gestão minudenciar sobre quais itens dever-se-á prestar contas.

A legislação paulista traz dispositivo idêntico, inclusive sobre o auxílio a ser prestado por auditoria externa, o que ganha grande importância uma vez que nos modelos de contrato de gestão firmados pelo estado de São Paulo para a gestão de serviços de saúde é permitido à contratada a aplicação dos recursos repassados no mercado financeiro, desde que os resultados dessa aplicação revertam-se, exclusivamente aos objetivos do referido contrato.

O controle realizado sobre as contas e demonstrativos financeiros da entidade deverá levar em consideração as regras constantes em regulamento próprio a ser aprovado pelo Conselho de Administração, contendo os procedimentos para a contratação de obras, serviços, compras e alienações e plano de cargos, salários e benefícios dos empregados da entidade (art. 4ํㅡ,

(3) Não obstante o dispositivo legal estabeleça que "o Poder Público poderá proceder à desqualificação da entidade como organização social, quando constatado o descumprimento das disposições contidas no contrato de gestão", entendemos, em consonância com Juarez Freitas, que a desqualificação nestes casos é dever e não faculdade do Poder Público. Para o autor, "Aqui, mais que nunca, verifica-se uma impropriedade, pois é obrigatória a desqualificação, em alguns casos, não se devendo admitir terrenos férteis a juizos subalternos ou a condescendências impertinentes". O Controle dos atos administrativos e os principios fundamentais, 3. ed. São Paulo: Malheiros Ed., 2004. p. 287. 
VIII). Necessário grifar que tal regulamento deve ser elaborado sob o manto dos princípios de Direito Administrativo, mormente aqueles previstos no art. 37, caput da Constituição da República. A este tópico, voltaremos oportunamente.

Desta breve análise dos principais dispositivos da legislação federal e da lei do estado de São Paulo, depreende-se que a nota característica do controle sobre as atividades desenvolvidas pelas organizações sociais é o resultado que se busca com a formalização do contrato de gestão.

Com efeito, a legislação é pródiga em mecanismos de autocontrole pelo resultado, preocupando-se intensamente com o cumprimento de metas e diretrizes; mas, sem maiores inquietações quanto aos meios que serão utilizados para alcançar-se estes fins.

\subsection{O Autocontrole das Organizações da Sociedade Civil de Interesse Público}

As OSCIPs foram instituidas, na esfera federal, pela Lei n. 9.790/99, regulamentada pelo Decreto n. 3.100/99 e surgiram, com menores desvirtuamentos que as organizações sociais, como forma de parceria entre o Estado e a sociedade civil para a realização de tarefas socialmente relevantes.

Os mencionados textos legais estabelecem alguns mecanismos de autocontrole destas entidades, uma vez que, embora em menores proporções, após firmado termo de parceria, as OSCIPs também poderão receber recursos públicos para custeio das atividades que desenvolvem.

Para qualificar-se como OSCIP a entidade interessada deverá constituir Conselho Fiscal ou órgão equivalente, com competência para opinar sobre os relatórios de desempenho financeiro e contábil e sobre as operações patrimoniais realizadas, emitindo pareceres para os organismos superiores da entidade (art. $4^{\circ}, \mathrm{III}$ ).

A lei não define a composição do Conselho Fiscal limitando-se a autorizar a participação de servidores públicos, vedada a percepção de remuneração ou subsídio, a qualquer título (art. $4^{\circ}$, parágrafo único).

Verifica-se que não há uma ingerência obrigatória do Poder Público no interior destas entidades, com atribuições de fiscalização e controle internos. Em outras palavras, o órgão responsável pelo autocontrole nas OSCIPs terá um outro perfil, mais próximo daquilo que se busca com o terceiro setor.

No regime das organizações sociais o Poder Público tem grande ascendência na direção e fiscalização internas daquela entidade. Ora, se o Estado pretende se utilizar do chamado terceiro setor para desenvolvimento de certas atividades deve agir de forma parceira, respeitando os limites existentes entre o Poder Público e estas pessoas juridicas de direito privado. Contudo, não pode delegar a gestão de atividades que the são próprias para 
a iniciativa privada - ainda que sociedades ou associações sem fins lucrativos -, imiscuir-se em seu gerenciamento e controle interno e ainda pretender que estas entidades prestem os serviços (que são públicos) sem submissão ao regime jurídico publicista. Ou seja, é o mesmo Estado, mas com outra "roupagem"; livre, portanto, das "amarras do regime público".

A Lei n. 9.790/99 também exige a realização de auditoria da aplicação dos recursos objetos do termo de parceria, inclusive por auditorias independentes se for 0 caso (art. $4^{\circ}$, VII, $c$ ). Note-se que aqui a auditoria independente não é obrigatória, devendo ser realizada quando o montante de recursos for maior ou igual a $\mathrm{R} \$ 600$ mil ou quando a OSCIP celebre, concomitantemente, vários termos de parceira com um ou vários órgãos estatais e cuja soma ultrapasse aquele valor (art. 19 e $\S 1^{\circ}$ do Decreto n. 3.100/99). Os dispêndios decorrentes dos serviços desta auditoria independente deverão ser incluídos no orçamento do projeto como item de despesa, podendo, para tanto, ser celebrado adiditivo (art. 19, $\S \S 3^{\circ}$ e e $4^{\circ}$ do Decreto n. 3.100/99).

Assim, ao menos em regra, a realização de auditoria para controle da aplicação dos recursos poderá ser feita pela própria entidade.

Os resultados atingidos com a execução do Termo de Parceria devem ser analisados por comissão de avaliação, formada em comum acordo entre o órgão parceiro e a OSCIP (art. 11, $\S 1^{\circ}$ ), devendo compor-se de dois membros do respectivo Poder Executivo, um da OSCIP e um membro indicado pelo Conselho de Política Pública da área de atuação correspondente (art. 20 do Decreto n. 3.100/99). Trata-se de outro exemplo de autocontrole da entidade uma vez que a avaliação de seus resultados será realizada, também, por um de seus membros.

Os arts. 12 e 13 da Lei n. 9.790/99 impõem aos responsáveis pela fiscalização do Termo de Parceria a obrigação de darem ciência imediata de qualquer irregularidade ou ilegalidade na utilização de recursos públicos ao Tribunal de Contas, Ministério Público e Advocacia Geral da União, sob pena de responsabilidade solidária.

A OSCIP deverá indicar, para cada Termo de Parceria, pelo menos um dirigente, que será responsável pela boa administração dos recursos recebidos (art. 22 do Decreto n. 3.100/99). Trata-se de outro traço do perfil do autocontrole nas OSCIPs na medida em que não obstante o controle que deve ser efetivado pelo Conselho Fiscal ou órgão equivalente, a legislação exige ao menos uma pessoa predeterminada para fiscalizar a boa administração dos recursos recebidos sob pena de responsabilidade solidária. Este controle deverá levar em consideração o regulamento contendo os procedimentos adotados para a contratação de obras e serviços, bem como para compras com emprego de recursos provenientes do Poder Público (art. 14).

Constata-se que embora o autocontrole na OSCIP guarde algumas diferenças pontuais com aquele disciplinado para as organizações sociais, aqui também o legislador primou por um controle de resultados, preterindo o controle dos meios necessários para alcançar-se o objetivo do Termo de Parceria. 


\section{CONTROLE DO TERCEIRO SETOR PELO PODER EXECUTIVO}

Os instrumentos de controle das entidades não estatais, que exercem atividades administrativas, possuem importância no processo de reconhecimento, classificação, fiscalização e fomentação pelo Estado.

Com efeito, o Terceiro Setor é a expressão utilizada para designar aquele segmento composto por organizações de direito privado, comprometidas com a realização de interesses da coletividade e proteção de valores da sociedade. Obviamente, o Estado, que por ventura queira utilizar-se do terceiro setor não pode se eximir de sua função primordial de promotor, fiscalizador e regulador da prestação dos serviços sociais.

Como bem asseverado por Juarez Freitas (4): "as organizações do terceiro setor (é dizer, em sentido amplo, as organizações privadas sem finalidade lucrativa $e$ as voltadas a finalidades socialmente relevantes (podem desempenhar um papel precioso na colmatação de lacunas da ação estatal. Todavia, não agir de maneira substitutiva ou excludente. Vale dizer, não devem alijar o Estado do cumprimento de suas funções indelegáveis na promoção do núcleo dos direitos fundamentais, mas, sim, desempenhar as tarefas atinentes à esfera de autonomia da sociedade."

Dessa forma, cabe ao Poder Executivo controlar a atuação dos envolvidos para garantir os direitos sociais constitucionalmente garantidos, haja vista que como lembrado por Juarez Freitas(5): "por força da contribuição de recursos orçamentários e bens do Estado, impõe-se alto grau de comprometimento com requisitos publicistas, mas sem pseudopublicização."

Nas Leis ns. 9.637/98 e 9.790/99, encontramos dispositivos claros sobre a atuação de um Poder Executivo Controlador.

Para fins didáticos, optamos por analisar os referidos dispositivos legais e, após transcrição, teceremos considerações e críticas consideradas necessárias para quiçá um aperfeiçoamento e adequação dos institutos ao nosso ordenamento jurídico, tendo como primazia sempre o princípio basilar do Estado Democrático de Direito: a supremacia do interesse público.

Pois bem, feitas as considerações preliminares, trataremos primeiramente dos dispositivos da Lei n. 9.637/98 (oriunda das Medidas Provisórias ns. 1.591 e 1.648) que regula as organizações sociais.

Tal lei, logo em seu artigo inaugural já apresenta considerações explícitas sobre a possibilidade de controle pelo Poder Executivo. Vejamos:

"Art. 1ㅇ O Poder Executivo poderá qualificar como organizações sociais pessoas jurídicas de direito privado, sem fins lucrativos, cujas atividades

(4) FREITAS, Juarez. op. cit., p. 281-282

(5) Id. Ibid., p.286. 
sejam dirigidas ao ensino, à pesquisa científica, ao desenvolvimento tecnológico, à proteção e preservação do meio ambiente, à cultura e à saúde, atendidos aos requisitos previstos nesta Lei."

Nesse compasso, pessoa jurídica de direito privado, sem fins lucrativos, com atividades previamente determinadas, pode ser qualificada como organização social pelo Poder Executivo. Além da ausência de finalidade de lucro e da específica atividade, estas entidades devem atender aos requisitos constantes no art. $2^{\circ}$ da Lei n. 9.637/98.

A qualificação consiste numa fase considerada preliminar, na qual entidades privadas sem fins lucrativos são declaradas aptas à prestação de serviços sociais. É o momento em que o Poder Executivo pode decidir e, conseqüentemente, exercer o controle sobre quais entidades reúnem os requisitos necessários a futuramente realizar contrato de gestão com o Estado.

Como ensina Paulo Modesto(6): "Mas ser organização social não significa apresentar uma estrutura jurídica inovadora, mas possuir um título jurídico especial, conferido pelo Poder Público em vista do atendimento de requisitos gerais de constituição e funcionamento previstos expressamente em lei. Esses requisitos são de adesão voluntária por parte das entidades privadas e estão dirigidos a assegurar a persecução efetiva dos fins de interesse público e fixar as garantias necessárias a uma relação de confiança e parceria entre a entidade provada e o Poder Público."

No art. $2^{\circ}$ da lei das organizações sociais, além do rol de requisitos especificos para que as entidades privadas habilitem-se a fim de obter a qualificação, em seu inciso II ainda prevê como requisito haver aprovação, quanto à conveniência e oportunidade de sua qualificação como organização social, por parte do Ministro ou titular de órgão supervisor ou regulador da área de atividade correspondente ao seu objeto social e do Ministro de Estado da Administração Federal e Reforma do Estado. Tal dispositivo mais uma vez ressalta de maneira cristalina a atuação do Poder Executivo como controlador de tais organizações sociais.

Contudo, é justamente no primeiro dispositivo que reside ponto crucial de controvérsia e crítica. Isto porque, apesar de tal previsão legal, a subjetividade do requisito conferindo ao administrador o poder de decisão quanto a qualificação, não nos parece em consonância com nosso ordenamento jurídico e com os princípios constitucionais que norteiam a Administração Pública. A palavra "poderá" confere ao Poder Executivo discricionariedade extrema, possibilitando a denegação arbitrária de pedidos de qualificação. Ademais, os indicados critérios de "conveniência e oportunidade", sem especificação devida, tampouco balizas suficientes, também soam como dotados de subjetividades inaceitáveis.

(6) MODESTO, Paulo. Reforma administrativa e marco legal das organizações sociais no Brasil - as dúvidas dos juristas sobre o modelo das organizações sociais. Revista Diálogo Jurídico, Salvador, ano 1, n. 9, p. 7, 2001. 
Pondera-se que a qualificação em si representa a possibilidade da organização social habilitar-se a eventualmente firmar com o Poder Público contrato de gestão. Não encerra todo o processo que atinge seu fim com a assinatura de tal contrato de gestão.

$\mathrm{Na}$ qualificação, cabe ao Poder Executivo conferir se houve o preenchimento de todos os requisitos legalmente determinados e mediante a comprovação de preenchimento de tais requisitos, "deverá" e não "poderá" emitir o certificado.

Considerando os pontos acima, a possibilidade da emissão de parecer não favorável à qualificação de entidade que tenha preenchido todos os requisitos legais é, no mínimo, um transpasse à segurança jurídica almejada por todos os componentes da sociedade, além de macular os princípios constitucionalmente consagrados da moralidade, impessoalidade, razoabilidade, legalidade e igualdade.

Assim, não é possivel aceitar qualquer critério de discricionariedade no momento da qualificação, a qual deveria ser vinculada ao atendimento dos requisitos identificados no art. $2^{\circ}$ da lei em comento. Possível aferição de conveniência e oportunidade deverá ocorrer quando do repasse do serviço e no momento da contratação e não em ato meramente declaratório da observância ou não de requisitos.

$\mathrm{Na}$ fase de qualificação o Poder Executivo se limita a garantir as condições devidamente previstas em lei de consolidação visando assim à operacionalidade desejada. A não qualificação poderá versar sobre o não enquadramento nas exigências específicas e não sobre circunstâncias que se correlacionem dinctamente ao contrato de gestão. Ou seja, não pode haver qualquer resquício de discricionariedade na fase de qualificação, já que atribui-se tão-somente a qualidade de organizações sociais colocadas à disposição do Estado para com ele contratar. Eventual contrato com o Poder Público ocorrerá em fase posterior. A qualificação possui o condão de apenas de identificar quais as empresas privadas preenchem os requisitos hábeis para a aprovação como organizações sociais.

Encontramos ainda o controle intenso do Poder Executivo no art. $3^{\circ}$, I, a da Lei n. 9.637/98 que dispõe que:

"O conselho de administração deve estar estruturado nos termos que dispuser o respectivo estatuto, observados, para os fins de atendimento dos requisitos de qualificação, os seguintes critérios básicos:

1 - ser composto por:

a) 20 a $40 \%$ (vinte a quarenta por cento) de membros natos representantes do Poder Público, definidos pelo estatuto da entidade;"

Em uma primeira leitura, tal prerrogativa de participação de representantes do Poder Público no Conselho de Administração, na proporção de 
$20 \%$ a $40 \%$, parece garantir ao Poder Executivo a possibilidade de fiscalização e acompanhamento do cumprimento das diretrizes e metas estabelecidas no contrato de gestão. Ou seja, um controle mais presente e ativo do Poder Executivo, representado por sua quota específica de membros natos.

Contudo, tal previsão legal, na verdade, induz a sociedade a erro, pois como ressaltado por Juarez Freitas (7): "o referido conselho é que deve aprovar o contrato de gestão (art. 4, 11 ), sendo este celebrado entre o Poder Público e a entidade qualificada, donde segue o risco de uma relação nada isenta entre as partes."

Após tais observações, a Lei n. 9.637/98, em sua Seção III traz a figura do contrato de gestão, que se traduz na formalização do vínculo entre o Estado e a organização social assim qualificada. Como preconizado por Marçal Justen Filho(8): "o contrato de gestão pode gerar uma delegação de serviço público, entendida a expressão em sentido amplo."

Com efeito, o contrato de gestão a ser travado entre Estado e a entidade qualificada, é considerado o ápice do processo que tem início com a qualificação de organização social pelo Poder Executivo, além de conter os principais vínculos de controle por parte do Estado sobre disciplinar as organizações sociais.

De maneira deficitária a lei das organizações sociais define (art. $\left.5^{\circ}\right) \circ$ contrato de gestão como "o instrumento firmado entre o Poder Público e a entidade qualificada como organização social, com vistas à formação de parceria entre as partes para fomento e execução de atividades relativas às áreas relacionadas no art. 1‥" Por sua vez, especificamente no parágrafo único do art. 6을 prevê mais um claro mecanismo de controle pelo Poder Executivo, ao dispor que "O contrato de gestão deve ser submetido, após aprovação pelo Conselho de Administração da entidade, ao Ministro de Estado ou autoridade supervisora da área correspondente à atividade fomentada". Ou seja, o contrato de gestão firmado entre o Estado e a organização social não se esgota com a assinatura do instrumento contratual, submetese ainda ao controle pelo Ministro do Estado.

No art. $7^{0}$ dispõe que da lei em comento, após rol de preceitos que devem ser observados na elaboração do contrato de gestão, o parágrafo único ainda dispõe que:

"Os Ministros de Estado ou autoridades supervisoras da área de atuação da entidade devem definir as demais cláusulas dos contratos de gestão de que sejam signatários".

Em seu art. $8^{\circ}$ a Lei n. 9.637/98 prevê ainda a execução e fiscalização do contrato de gestão ao determinar que:

(7) FREITAS, Juarez. op. cit., p. 285.

(8) JUSTEN FILHO, Marçal. Curso de direito administrativo. 2 ed., São Paulo: Saraiva. 2006. p. 139. 
"A execução do contrato de gestão celebrado por organização social será fiscalizada pelo órgão ou entidade supervisora da área de atuação correspondente à atividade fomentada.

$\S 10$ A entidade qualificada apresentará ao órgão ou entidade do Poder Público supervisora signatária do contrato, ao término de cada exercício ou a qualquer momento, conforme recomende o interesse público, relatório pertinente à execução do contrato de gestão, contendo comparativo especifico das metas propostas com os resultados alcançados, acompanhado da prestação de contas correspondente ao exercício financeiro.

$\S 2$ Os resultados atingidos com a execução do contrato de gestão devem ser analisados, periodicamente, por comissão de avaliação, indicada pela autoridade supervisora da área correspondente, composta por especialistas de notória capacidade e adequada qualificação.

$\S 3^{\circ}$ A comissão deve encaminhar à autoridade supervisora relatório conclusivo sobre a avaliação procedida."

Por fim, além de todas as prerrogativas de controle do Poder Executivo, cabe ainda a ele a desqualificação da entidade como organização social, quando constatado o descumprimento das disposições contidas no contrato de gestão.

De certo, a desqualificação não ocorrerá ao bel-prazer do Poder Executivo. Aqui cabe mais uma ressalva, pois de igual modo como acontece com a qualificação, a desqualificação também é ato discricionário. Isto porque a lei em comento, em seu art. 16 estabelece que o Poder executivo "poderá" proceder à desqualificação.

Conforme os $\S \S 1^{\circ}$ e $2^{\circ}$ do art. 16 a desqualificação necessariamente será precedida de processo administrativo, assegurado o direito de ampla defesa, respondendo os dirigentes da organização social, individual e solidariamente, pelos danos ou prejuizos decorrentes de sua ação ou omissão.

Ora, se constatado o descumprimento das disposições contidas na lei ou no contrato de gestão, o Poder Executivo tem o dever de desqualificar a organização social, não sendo, portanto crivel que se aceite discricionariedade nesses casos. A discricionariedade tanto na qualificação como na desqualificação deve ser banida.

Preciosa a lição de Juarez Freitas(9): "Aqui, mais do que nunca, verifica-se uma impropriedade, pois é obrigatória a desqualificação, em alguns casos, não se devendo admitir terrenos férteis a juizos subalternos ou a condescendências impertinentes."

(9) FREITAS, Juarez. Op. cit., p. 287. 
Com efeito, após a desqualificação a entidade deve restituir ao Poder Público contratante o saldo dos recursos líquidos resultantes dos valores dele recebidos, bem como todo o patrimônio, os legados ou doações que Ihe foram destinados e os excedentes financeiros.

Tratamos até o momento das peculiaridades do controle do Poder Executivo nas organizações sociais, trazendo as principais disposições da Lei n. $9.637 / 98$ sobre o tema.

A seguir procuraremos demonstrar as peculiaridades da Lei n. 9.790, de 23 de março de 1999, que dispõe sobre a qualificação de pessoas jurídicas de direito privado, sem fins lucrativos, como Organizações da Sociedade Civil de Interesse Público (OSCIPs), no que concerne à possibilidade de controle do Poder Executivo.

Inicialmente, cabe enfatizarmos que considerável parte dos dispositivos que constam na lei das organizações sociais também se aplicam as OSCIPS (controle dos Tribunais de Conta da União, ausência de finalidade de lucro, obediência a princípios constitucionais etc.).

Para a qualificação de referida figura, necessário que seja pessoa jurídica de direito privado, sem fins lucrativos e que seus objetivos sociais e normas estatutárias cumpram os requisitos devidamente limitados pela própria lei em comento.

Observe-se que diferentemente das organizações sociais, a outorga de qualificação das OSCIPs é vinculada ao cumprimento dos requisitos instituidos na lei, conforme o $\S 2^{\circ}$, do art. $1^{\circ}$. Ou seja, o legislador acertadamente ao instituir tal previsão legal, retirou da Administração Pública qualquer discricionariedade na outorga de título de qualificação. Assim, ao transferir a responsabilidade de adequação aos requisitos legais às pessoas juridicas de direito privado, sem fins lucrativos, há uma redução da margem de discricionariedade das autoridades administrativas, já que ao receber documentação incompleta ou errada indefere o pedido e a entidade tem que iniciar 0 processo novamente.

Assim, o dispositivo que prevê que a qualificação é ato vinculado ao cumprimento dos requisitos da lei, torna muito mais célere e transparente o processo de qualificação. Isto porque a entidade é que será a responsável pelo envio da documentação correta e em consonância com o exigido pela lei, sendo a qualificação automática se cumpridos os preceitos legais.

A qualificação como OSCIP não significa necessariamente que a entidade irá firmar Termo de Parceria com órgãos governamentais e, portanto, receber recursos públicos para a realização de projetos. Representa apenas a aptidão de determinada entidade para eventual realização de Termo de Parceria. 
O trâmite legal para a qualificação encontra-se detalhadamente previsto nos arts. $5^{\circ}$ e $6^{\circ}$ da Lei n. 9.790/99, quando o Poder Executivo terá controle total da outorga ou não do certificado de qualificação da requerente como OSCIP.

Registre-se que a pessoa jurídica de direito privado sem fins lucrativos, desde que preencha os requisitos dos arts. $2^{\circ}$ e $3^{\circ}$ da lei em comento, deverá formular requerimento escrito ao Ministério da Justiça manifestando a intenção de receber a qualificação de OSCIP. Tal pedido deve ser instruído com documentos previstos nos incs. I a $V$ do art. $5^{\circ}$ da Lei n. 9.790/99. Após, cabe ao Poder Executivo, representado pelo Ministério da Justiça deferir ou não o requerimento de qualificação no prazo de 30 dias.

Os casos de indeferimento estão devidamente previstos no $\S 3^{\circ}$, do art. $6^{\circ}$ da lei, quais sejam: I - a requerente enquadrar-se nas hipóteses previstas no art. $2^{\circ}$ da Lei; 11 - a requerente não atender aos requisitos descritos nos arts. $3^{\circ}$ e $4^{\circ}$ da Lei e 111 - a documentação apresentada estiver incompleta.

Assim, em sede federal o controle da qualificação é do Poder Executivo, através do Ministério da Justiça. Caso seja deferido, o próprio Ministério da Justiça irá emitir, no prazo de 15 dias da decisão, o certificado de qualificação da requerente como Organização da Sociedade Civil de Interesse Público. Com este documento, a entidade encontra-se apta a celebrar termo de parceria com o Estado, que como disposto no art. $9^{\circ}$ da lei, é: "instrumento passivel de ser firmado entre o Poder Público e as entidades qualificadas como Organizações da Sociedade Civil de Interesse Público destinado à formação de vinculo de cooperação entre as partes, para o fomento e a execução das atividades de interesse público previstas no art. 3 desta Lei."

No próprio Termo de Parceria deve haver previsibilidade expressa do controle do Poder Executivo já que uma das cláusulas essenciais a este documento (art. 10, V) é "a que estabelece as obrigações da Sociedade Civil de Interesse Público, entre as quais a de apresentar ao Poder Público, ao término de cada exercício, relatório sobre a execução do objeto do Termo de Parceria, contendo comparativo especifico das metas propostas com os resultados alcançados, acompanhado de prestação de contas dos gastos e receitas efetivamente realizados, independente das previsões mencionadas no inciso IV"; além de tal expressa previsão que visa nada mais do que a possibilidade de controle do cumprimento do objeto de parceria, o art. $11 \mathrm{da}$ lei ainda prevê que "a execução do objeto do Termo de Parceria será acompanhada e fiscalizada por órgão do Poder Público da área de atuação correspondente à atividade fomentada, e pelos Conselhos de Políticas Públicas das áreas correspondentes de atuação existentes, em cada nivel de governo".

Aqui, mais uma vez acertou o legislador ao não obrigar a necessidade de representantes do Poder Público na acima citada comissão de avaliação, que será composta de comum acordo entre o "órgão parceiro" e a organização da sociedade civil. 
Por fim, cabe ainda tratar da possibilidade de desqualificação das OSCIPs. No art. $8^{\circ}$ da Lei n. 9.790/99, a desqualificação, diferentemente do que ocorre nas Organizações Sociais, aparece não como uma faculdade, mas, como um dever. Aliás, a própria sociedade poderá solicitar, vejamos:

"Art. $8^{\circ}$ Vedado o anonimato, e desde que amparado por fundadas evidências de erro ou fraude, qualquer cidadão, respeitadas as prerrogativas do Ministério Público, é parte legítima para requerer, judicial ou administrativamente, a perda da qualificação instituída por esta Lei."

A desqualificação ainda poderá ocorrer a pedido ou mediante decisão proferida em processo administrativo ou judicial, de iniciativa popular ou do Ministério público, conforme o disposto no art. 7.

Acertou o legislador ao ampliar a todo e qualquer cidadão a possibilidade de requerer, seja na esfera judicial ou na administrativa, a desqualificação de determinada OSCIP. Obviamente, tal desqualificação necessariamente deverá ser baseada em evidente erro ou fraude.

\section{CONTROLE PELO TRIBUNAL DE CONTAS}

Os Tribunais de Contas ${ }^{(10)}$ são órgãos auxiliares do Poder Legislativo na função de fiscalização contábil, financeira, orçamentária, operacional e patrimonial da União e das entidades da administração pública direta e indireta, quanto à legalidade, legitimidade, economicidade, aplicação das subvenções e renúncias de receitas (arts. 70 e 71, CF/88).

Nota-se que os Tribunais de Contas são órgãos auxiliares do Poder Legislativo na fiscalização do dinheiro público. Todo o cidadão tem o direito de denunciar a estes tribunais irregularidade e ilegalidade verificadas contra o patrimônio público. Estas instituições exercem o controle sobre as despesas da espécie considerando principalmente os princípios que resguardam o interesse público.

As Leis ns. 9.637/98 e 9.790/99 prevêem expressamente a possibilidade de controle pelo Tribunal de Contas sobre as OS e as OSCIPS.

A Lei n. 9.637/98, através de seu art. 9², dispõe que: "Os responsáveis pela fiscalização da execução do contrato de gestão, ao tomarem conhecimento de qualquer irregularidade ou ilegalidade na utilização de recursos ou bens de origem pública por organização social, dela darão ciência ao Tribunal de Contas da União, sob pena de responsabilidade solidária."

(10) Existem Tribunais de Contas Municipais nas cidades de São Paulo e do Rio de Janeiro. Entretanto, após a promulgação da Constituição Federal de 1988, nenhum outro município brasileiro pôde criar seu próprio Tribunal de Contas. Nestes casos, é da competência dos Tribunais de Contas dos Estados a fiscalização das contas públicas municipais. 
No mesmo sentido, a Lei n. 9.790/99 em seu art. 4ํ, VII, $d$, dispõe: “d) a prestação de contas de todos os recursos e bens de origem pública recebidos pelas Organizações da Sociedade Civil de Interesse Público será feita conforme determina o parágrafo único do art. 70 da Constituição Federal."

Por conseguinte, em seu art. 12 assevera que "os responsáveis pela fiscalização do Termo de Parceria, ao tomarem conhecimento de qualquer irregularidade ou ilegalidade na utilização de recursos ou bens de origem pública pela organização parceira, darão imediata ciência ao Tribunal de Contas respectivo e ao Ministério Público, sob pena de responsabilidade solidária".

Pois bem, tanto na Lei n. 9.637/98, como na Lei n. 9.790/99, existem disposições em relação à possibilidade de controle do Tribunal de Contas de toda a atividade das quais participam recursos públicos e destinação do fomento.

Dessa forma, cabe ao Tribunal a atividade fiscalizadora, com os devidos ajustes que envolvem os entes pertencentes ao Terceiro Setor, com base na Constituição Federal e nas Leis Federais ns. 8.666/93, 9.637/98 e 9.790/99. Urge ressaltar que o controle efetuado pelo Tribunal de Contas não se limita à aprovação ou não da utilização de recursos ou bens de origem pública pela organização social ou pela OSCIP. Além de fiscalizar eventual irregularidade na utilização das verbas públicas repassadas, ainda pode requerer informações outras com a determinação de que os processos submetidos à auditoria sejam instruídos com dados sobre o quanto vem sendo cumprido dos compromissos assumidos no contrato; que tipo de contratações foram feitas com recursos públicos e se foram com permissão contratual e de modo adequado; se os investimentos realizados com recursos públicos atenderam a previsão contratual e de modo adequado.

Tal possibilidade encontra-se devidamente exemplificada através do Acórdão TC 027475/026/00, do Tribunal de Contas do Estado de São Paulo, Processo n. 27475/026/00, relator Conselheiro Renato Martins Costano.

Outra possibilidade é a prestação de contas ser considerada regular, mas com ressalvas. Assim, o Tribunal de Contas poderá recomendar que a organização social ou OSCIP passe, por exemplo, a exigir notas fiscais de despesas devidamente preenchidas; evitar gastos relacionados com a manutenção de hospital; aprimorar seus controles de estoques; incluir o valor dos bens permanentes adquiridos pela secretaria vinculada antes do início das atividades etc.

No próprio julgado, pode haver a fixação de prazo para que as organizações sociais comprovem, junto ao Tribunal, ter providenciado o correto e adequado ajustamento de seus atos constitutivos às exigências legais de sua qualificação. 
A hipótese acima pode ser encontrada de maneira concreta através dos Acórdãos TC 031304/026/01, TC 027474/026/2000, TC 027471/026/2000, TC 010998/026/02, relator Conselheiro Cláudio Ferraz de Alvarenga; TC 006816/026/99, TC 006817/026/99, TC 006818/026/99, relatores ConseIheiro Fulvio Julião Biazzi e Conselheiro Cláudio Ferraz de Alvarenga; TC 13709/026/03, TC 13710/026/03, Conselheiro Robson Marinho, do Tribunal de Contas do Estado de São Paulo.

Ademais, quando não houver aprovação da prestação de contas, desde que devidamente fundamentada, o Tribunal de Contas além de julgar irregular as prestações de contas dos recursos públicos repassados às OS e/ou OSCIPs, poderá ainda aplicar multa por infração legal, conforme Acórdão n. TC 033449/026/00, relator Conselheiro Eduardo Bittencourt Carvalho e Antônio Roque Citadini.

\section{O CONTROLE SOCIAL}

O Controle Social, como o nome sugere, é aquele exercido pela sociedade em relação não só aos serviços prestados pelas organizações sociais e OSCIPs, como também no que tange à aplicação e gerenciamento dos recursos públicos recebidos por estas entidades. Assim, a legislação que instituiu estas novas formas de qualificação previu alguns mecanismos de controle social. Outros são extraídos do próprio ordenamento jurídico em razão do fato de haver repasse e aplicação de recursos públicos.

Analisaremos as formas deste tipo de controle sobre as organizações sociais e organizações da sociedade civil de interesse público conjuntamente, pontuando, quando o caso, as principais notas comparativas.

Já foi dito neste trabalho que o surgimento destas novas formas de relação entre o Estado e as organizações privadas, através das organizações sociais e organizações da sociedade civil de interesse público, são parte de um programa de reforma do Estado, onde se objetivava, dentre outros escopos, diminuir a dicotomia existente entre público e privado, alterando a estrutura do planejamento e da execução de políticas públicas, de sorte a transformálas em políticas públicas de um espaço governamental e não governamental. A idéia foi a de estabelecer uma parceria entre Estado e sociedade civil em todos os niveis, incluindo a elaboração, passando pela execução, monitoramento, avaliação e fiscalização das políticas públicas. Criou-se a imagem de que o público não é monopólio do Estado. Houve, portanto, uma profunda modificação na relação público/privada o que exigiu o mesmo grau de alteração no controle da sociedade sobre esta nova relação. Já não se verificava uma relação estanque e separada entre Estado e sociedade, tendo o ordenamento jurídico progressivamente incorporado a intersecção em muitas áreas de forma a valorizar a cidadania e a responsabilização. 
Todavia, a sociedade brasileira é historicamente amorfa e com pequena capacidade intrínseca de organização. Assim, aqueles que não fazem parte de grupos ou classes organizadas ficam à margem, já que o pouco que desfrutamos de democracia é corporativista. Desta feita, não obstante a crescente previsão de formas de controle social, nos mais diversos diplomas jurídicos, estas não são suficientes para garantir com efetividade que este controle se verifique.

O grande risco, portanto, destas novas formas de interação entre público e privado, tendo em vista a realidade de organização da sociedade brasileira, é o uso do Estado em benefício de poucos, permitindo maior participação e maior transparência a certos grupos sociais em detrimento de outros. É a captura do Estado que ocorre quando um grupo de pessoas perpassa o público fazendo uso da máquina de governo para benefício próprio.

Feitas estas breves considerações, passaremos à análise dos mecanismos de controle social previstos pela legislação que instituiu as organizações sociais e organizações da sociedade civil de interesse público.

Traço comum nas leis em análise é a exigência de publicidade dos mais diversos atos praticados na execução do contrato de gestão ou Termo de Parceria. Com efeito, como não poderia deixar de ser, o princípio da publicidade foi adotado, não só expressamente (art. $4^{\circ}$ da Lei n. 9.790/99), como também através da obrigatoriedade de publicação de relatórios financeiros e de execução ${ }^{(11)}$; da exigência de publicação do contrato de gestão e do termo de parceria firmados com o poder público ${ }^{(12)}$; da exigência de publicação do nome do dirigente da OSCIP que será responsável pela boa administração dos recursos públicos ${ }^{(13)}$; da exigência de publicação do regulamento adotado para a realização de compras e o plano de cargos e salários ${ }^{(14)}$.

Observe-se, no entanto, que todas esta publicações devem ser feitas na imprensa oficial, não havendo, em nenhum dos casos, exigência de publicação em jornal de grande circulação a fim de dar maior eficácia ao princípio da publicidade. Com efeito, apenas quando trata da publicação de relatório de atividades e das demonstrações financeiras da entidade, que deverá ser feita no encerramento do exercício fiscal, o art. $4^{\circ}, \mathrm{VII}, b$ faz referência à publicidade "por qualquer meio eficaz", sem, contudo, indicar qual seria este meio.

O órgão colegiado de deliberação superior das organizações sociais deve abarcar em sua composição membros da comunidade, de notória ca-

(11) Arts. 4ํ, VII, $b$ da Lei n. 9.790/99; art. $2^{\circ}$, I, $f$ da Lei n. 9637/98; art. $9^{9}, \S 1^{9}$ e 12 da Lei Complementar do Estado de São Paulo n. 846/98.

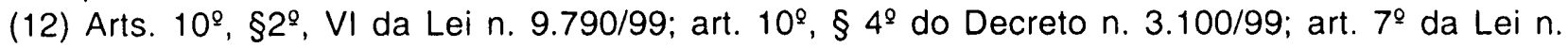
9.637/98; art. $6^{9}, \S \S 3^{9}$ e $4^{9}$ e art. $7^{9}$ da Lei Complementar do Estado de São Paulo n. 846/98.

(13) Art. 22, parágrafo único do Decreto n. 3.100/99.

(14) Arts. 14 da Lei n. 9.790/99; art. 17 da Lei n. 9.637/98; art. 19 da Lei Complementar do Estado de São Paulo n. 846/98. 
pacidade profissional e idoneidade moral (art. $2^{\circ}, 1, d$ da Lei n. 9.637/98 e art. $2^{\circ}$, I, $d$ da LC/SP n. 846/98). Todavia, estes membros da comunidade serão eleitos pelos demais integrantes do Conselho, que serão ou representantes do Poder Público ou membros da própria associação. Assim, não há qualquer garantia da imparcialidade destes escolhidos. Atente-se, ainda, para a exigência de notória capacidade profissional e idoneidade moral sem haver, contudo, qualquer previsão legal de requisitos mínimos para se aferir tal qualidade. Igualmente, não há qualquer exigência de tais pessoas fazerem parte de grupo organizado com comprovada atuação na área de execução do contrato de gestão. Em verdade, tem-se a impressão que a eleição destes membros da sociedade coaduna-se com a "discricionariedade" própria deste novel instituto.

As OSCIPs, por seu turno, sofrem amplo controle pelos Conselhos de Políticas Públicas, grupos formados por diversos atores vinculados a uma determinada política pública e que têm por objetivo ampliar a participação popular e garantir a descentralização do poder, fortalecendo a sociedade democrática. São compostos por representantes do Estado e da sociedade, estes últimos pertencentes a entidades eleitas em fórum específico.

A lei vincula a celebração do Termo de Parceria à prévia consulta ao Conselho de Políticas Públicas da área de atuação correspondente, no respectivo nivel de governo (art. $10 \S^{\circ}$ ). Esta consulta não é vinculante e é dispensada no caso de inexistir um Conselho de Política Pública na respectiva área (arts. 10, $\S \S 1^{\circ}$ e $2^{\circ}$ do Decreto n. 3.100/99).

Na mesma linha o Conselho de Política Pública é apontado como um dos agentes fiscalizadores da execução do objeto do Termo de Parceria (art. 11), podendo encaminhar recomendações e sugestões ao órgão estatal parceiro que deverá tomar as providências que entender cabíveis e prestar informação a este conselho, garantindo, assim, um retorno das observações feitas (art. 17 e parágrafos do Decreto n. 3.100/99).

O Conselho surge ainda integrando a comissão de avaliação dos resultados atingidos pelo Termo de Parceria, através da indicação de um dos membros desta comissão (art. $11, \S 1^{\circ}$ da Lei n. 9790/99 e art. 20 do Decreto n. 3.100/99).

Por fim, no procedimento concorrencial previsto pela lei para a escolha de OSCIP que celebrará Termo de Parceria com o Poder Público, o Conselho indicará um membro para compor a comissão julgadora do concurso.

No panorama apresentado, o Conselho de Política Pública surge como importante instrumento de controle social, não só da execução do Termo de Parceria, mas, o que nos parece mais relevante, na sua formação, devendo analisar, inclusive, a necessidade de formalização de tal instrumento. Assim, ainda que sem força vinculante, o parecer do Conselho de Politica Pública pode indicar o caminho com, pelo menos, um mínimo de respaldo popular. 
Cumpre consignar que não somos ingênuos a ponto de ver no ConseIho de Política Pública um fiel retrato dos anseios da sociedade, até porque sua formação é híbrida (com representantes do Poder Público) e, não raras vezes marcada por forte pressão deste mesmo Poder Público. Entretanto, trata-se de uma pequena itha de controle social (principalmente no que concerne à formação do Termo de Parceria) no oceano de discricionariedade de que se cercou o Poder Público.

O Ministério da Justiça permitirá, mediante requerimento dos interessados, livre acesso público a todas as informações pertinentes às OSCIPS (art. 17 da Lei n. 9790/99). Também deverá a organização colocar os relatórios financeiro e de atividades à disposição para exame de qualquer cidadão (art. $4^{\circ}, \mathrm{VII}, b$ ).

Estes instrumentos representam significativo avanço, pois permitem o exercício de controle social, na medida em que disponibilizam a qualquer cidadão as informações pertinentes à gestão do Termo de Parceria. Em verdade, tais dispositivos dão concretude ao art. 37, inc. XXI, $\S 3^{\circ}$, II que confere ao usuário formas de participação na administração, especialmente quanto ao acesso a registros administrativos e a informações sobre atos de governo(15).

Não obstante, não se verifica a mesma preocupação no regime das organizações sociais. O controle social das ações de forma transparente surge como diretriz do Programa Nacional de Publicização; mas, não há previsão de qualquer instrumento que realize este vetor.

Tratando da desqualificação da entidade como OSCIP, ela pode ser requerida por qualquer cidadão, judicial ou administrativamente, desde que amparada por fundadas evidências de erro ou fraude, vedado o anonimato e respeitada as prerrogativas do Ministério Público (art. $\left.8^{\circ}\right)^{(16)}$. Nota-se claramente a preocupação do legislador que, se por um lado desejou ampliar os contornos do controle social, por outro, inseriu instrumentos para coibir o mau uso deste mecanismo - com viés político, v. g. - exigindo "fundadas exigências de erro ou fraude". Em que pese esta cautela, parece-nos que esta limitação pode inviabilizar a prática do controle, pois sempre será mais difícil para o cidadão comum reunir evidências da prática de irregularidades. Ainda, não parece que as principais irregularidades que sói verificar no âm. bito da gestão do Termo de Parceria estejam vinculadas ao erro. Mesmo a fraude é apenas uma das facetas da ilegalidade, não sendo suficiente para abarcar todas as suas possibilidades. Assim, talvez melhor seria a possibilir dade da iniciativa popular para a desqualificação da entidade em quaisquer:

(15) "Art. 37, XXI, § 3, II - a lei disciplinará as formas de participação do usuário na administração pública direta e indireta, regulando especialmente: $11-0$ acesso dos usuários a registros administrativos e a informações sobre atos de governo, observado o disposto no art. $5^{\circ}$, X e XXXIII."

(16) Vide art. $4^{9}$ do Decreto n. 3.100/98. 
casos de irregularidade e ilegalidade, opção que melhor atenderia a um amplo controle social e aos princípios que informam o regime público a que devem se submeter estas entidades.

Não se encontra a mesma possibilidade para a desqualificação das organizações sociais. Neste caso, incumbe ao Poder Executivo a desqualificação não havendo qualquer menção à iniciativa popular.

\section{CONCLUSÕES}

Todos os diplomas analisados no presente trabalho trazem a previsão genérica da possibilidade de controle social. Assim, a Lei n. 9.637/98 dá ao controle social status de diretriz o Plano Nacional de Publicização (art. 20, III).

A LC/SP n. 846/98 qualifica qualquer cidadão como parte legítima para denunciar irregularidades cometidas pelas organizações sociais ao Tribunal de Contas ou à Assembléia Legislativa (art. 11).

A Lei n. 9.790/99 sujeita os Termos de Parceria aos mecanismos de controle social previstos na legislação (art. 11, $\S 3^{\circ}$ ).

Muito embora tais dispositivos prestem-se a conferir aos referidos diplomas um perfil de legislação preocupada com a garantia de um controle social, todos os direitos extraiveis dos dispositivos acima indicados já eram albergados pelo ordenamento jurídico, nada representando em termos de inovação nos mecanismos de controle social.

Diante do panorama exposto conclui-se que o regime jurídico conferido às OSCIPs permite melhores mecanismos de controle social - desde a sua qualificação, passando pela gestão do Termo de Parceria e chegando à possibilidade de iniciativa popular para a desqualificação. Não é um sistema ideal, comportando diversas críticas; mas, demonstra um maior avanço no sentido de instrumentalizar o controle social.

O regime jurídico aplicado às organizações sociais, por sua vez, constitui verdadeiro retrocesso em termos de controle social, pois alija a sociedade de qualquer participação, limitando-se a estabelecer de forma genérica o "controle social". Com efeito, a qualificação da entidade como organização social, de forma absolutamente discricionária (art. $2^{\circ}$, II, Lei n. 9.637/98) já é suficiente para impossibilitar qualquer forma de controle social.

O mesmo raciocínio se aplica quando da formalização do contrato de gestão. Novamente, verifica-se grande margem de discricionariedade nas entidades escolhidas e na gestão das atividades que serão absorvidas. Não há espaço para a oitiva de qualquer organismo que represente a sociedade para pautar as escolhas do administrador. Não há previsão de qualquer audiência pública. Não há qualquer explicação sobre a escolha efetivada. Nada. Apenas a "discricionariedade". 
Verifica-se, portanto, que as organizações sociais estão bem mais próximas do Poder Executivo, sofrendo intenso controle do órgão gestor do contrato. Estão afastadas da sociedade e, portanto, de seus mecanismos de controle. Assim, ao contrário de induzir a uma complementaridade traço marcante do terceiro setor, as organizações sociais representam uma forma de burla aos princípios do direito público.

Neste ponto, preciosa a conclusão de Juarez Freitas, com a qual concordamos: "Por tudo, pelo risco de configurar desvirtuamento, o modelo federal das organizações sociais deve ser entendido como extremamente afrontoso a princípios e regras que regem as relações de administração (...) Perante tais equívocos, resulta incontendivel que o diploma de regência das organizações sociais precisa desaparecer, devendo o legislador cuidar de que o terceiro setor atue somente de modo complementar à ação estatal, remanescendo para situações marcadamente excepcionais, o agir no espaço dantes ocupado por entidades públicas, desde que comprovadamente não possam ser mantidas na esfera pública estatal e prestem serviços em relação aos quais não se mostra conveniente (ao interesse público) o regime de execução indireta, por meio de concessões, permissões ou autorizações (que supõem lucratividade)."

Por fim, concluímos que:

1. O Estado não pode, a pretexto de utilizar-se de instrumentos do terceiro setor, esquivar-se da subsunção de sua atuação ao regime jurídico de direito público.

2. A exigência na composição do Conselho de Direção das organizações sociais de $20 \%$ a $40 \%$ de membros natos representantes do Poder Público, embora possa significar, em uma primeira leitura, um maior controle, na verdade constitui forma de maquiar a subsidiariedade que deve nortear as relações com o terceiro setor já que se trata do mesmo Estado, mas, com outra "roupagem"; livre, portanto, das "amarras do regime público".

3. O controle exercido sobre as organizações sociais e as OCIP's é um controle eminentemente de resultados sem maiores preocupações com os meios utilizados para tanto.

4. O Poder Executivo que pretenda se valer do terceiro setor não pode se eximir de seu papel de promotor, fiscalizador e controlador da prestação dos serviços sociais.

5. O terceiro setor não pode ser usado como forma de transferência de responsabilidade para a sociedade civil, mas, sim, de cooperação privada com o Poder Público.

6. A sociedade brasileira não possui estrutura cultural para absorver os mecanismos de controle social e torná-los eficazes. A mera importação 
de institutos do terceiro setor sem a devida adequação à realidade nacional pode levar à frustração do modelo que se pretende implementar.

7. Após a análise dos mecanismos de controle das organizações sociais e OSCIPs, necessário se faz responder à seguinte questão: Ao invés de criar formas alternativas de prestação de serviços públicos através de sua delegação à gestão privada não seria mais eficaz investir em uma reforma que tornasse o Estado mais eficiente para o desenvolvimento das atividades que the são afetas?

\section{REFERÊNCIAS}

BARREIRA, Maria Cecília Roxo Nobre; CARVALHO, Maria do Carmo Brant (Orgs). Tendências e perspectivas na avaliação de políticas e programas sociais. São Paulo: IEE/PUC-SP, 2001.

BUGARIN, Maurício Soares; VIEIRA, Laércio Mendes; GARCIA, Leice Maria. Controle dos gastos públicos. Ed. Konrad Adenauer Stifung.

CATTANI, Antônio David (Org.). A outra economia. Porto Alegre: Ed. Veraz, 2003.

COUTINHO, Joana Aparecida. ONG's e politicas neoliberais no Brasil. Doutorado em Ciências Sociais. São Paulo: PUC, 2004.

FALCÃO, Joaquim. Democracia, direito e terceiro setor. Rio de Janeiro: Editora FGV, 2004.

FERRAREZI, Elisabete. O novo marco legal do terceiro setor no Brasil. Espanha: Revista del CLAD Reforma y Democracia, n. 20, 2001.

JUSTEN FILHO, Marçal. Curso de direito administrativo. 2. ed. São Paulo: Saraiva, 2006.

BACELAR FILHO, Romeu Felipe (Coord.). Direito administrativo contemporâneo. Estudos em homenagem ao Professor Manoel de Oliveira Franco Sobrinho. Belo Horizonte: Ed. Fórum, 2004.

FREITAS, Juarez. O controle dos atos administrativos e os principios fundamentais. São Paulo: Malheiros Editores, 3ª edição, 2004.

IOSCHIPE, Evelyn Berg (Org.). $3^{\circ}$ Setor - Desenvolvimento social sustentado. Rio de Janeiro: Paz e Terra, 1997.

MESTRINER, Maria Luiza. O Estado entre a filantropia e a assistência social. São Paulo: Cortez, 2001.

A proteção social das organizações sem fins lucrativos - a regulação estatal da filantropia e da assistência social no Estado Brasileiro. São Paulo: PUC. Doutorado Serviço Social, 2000. 
MODESTO, Paulo. Reforma administrativa e marco legal das organizações sociais no Brasil - as dúvidas dos Juristas sobre o modelo das organizações sociais. Revista Diálogo Jurídico, Salvador, ano 1, n. 9, 2001.

MONTAÑO, Carlos. $3^{\circ}$ setor e questão social - crítica ao padrão emergente de intervenção social. São Paulo: Cortez Editora, 2002.

OLIVEIRA, Sidney Benedito. Ação social e terceiro setor no Brasil. Mestrado em Economia Política. São Paulo: PUC, 2005.

PAES, José Eduardo Sabo. Fundações e entidades de interesse social Aspectos jurídicos, administrativos, contábeis e tributários. 5. ed. Brasília: Brasilia Jurídica, 2004.

PEREIRA, Luiz Carlos Bresser. A reforma do estado dos anos 90: lógica e mecanismo de controle. Disponivel em: http://www.clad.org.ve/fulltext/0030101.htm/ RAMOS, Rosely. Um Estudo sobre os instrumentos de controle orçamentário e financeiro das Entidades descentralizadas e o seu papel no programa de ajuste do Estado. São Paulo: Monografia PUC, 1998.

SANTANA, Ângela. A reforma do Estado no Brasil: estratégias e resultados. In: VII Congresso Internacional del CLAD sobre la Reforma del Estado y de la Administráción Pública, Lisboa, Portugal, 8-11, oct. 2002.

SIQUEIRA, Elisabete Stradiotto. A produção da casa na construção do sonho: o papel das ONGs na gestão de recursos públicos/privados de habitação. São Paulo: PUC, Doutorado Ciências Sociais, 1999. 